\title{
An overview of Australia's Phytophthora species assemblage in natural ecosystems recovered from a survey in Victoria
}

\author{
William A. Dunstan¹, Kay Howard ${ }^{1}$, Giles E. StJ. Hardy ${ }^{1}$, and Treena I. Burgess ${ }^{1}$
}

${ }^{1}$ Centre for Phytophthora Science \& Management, School of Veterinary and Life Sciences, Murdoch University, South Street, Murdoch, WA 6150, Australia; corresponding author e-mail: G.Hardy@murdoch.edu.au

\begin{abstract}
Although Phytophthora species cause serious diseases worldwide, until recently the main focus on disease in natural ecosystems in southern Australia has been on the distribution and impact of $P$. cinnamomi. However, new Phytophthora pathogens have emerged from natural ecosystems, and there is a need to better understand the diversity and distribution of these species in our natural forests, woodlands and heathlands. From a survey along a $70 \mathrm{~km}$ pipeline easement in Victoria, Phytophthora species were isolated from 249 rhizosphere samples and 25 bait bags deployed in 21 stream, river, or wetland locations. Of the 186 Phytophthora isolates recovered, 130 were identified to species based on ITS sequence data. Ninety-five isolates corresponded to 13 described Phytophthora species while additionally 35 isolates were identified as Clade 6 hybrids. Phytophthora cinnamomi was the most common species isolated (31\%), followed by $P$. elongata $(6 \%)$, both species were only recovered from soil. Samples from sites with the highest soil moisture at the time of sampling had the highest yield of isolates. Consistent with other studies throughout the world, Clade 6 species and their hybrids dominated water samples, although many of these species were also recovered less frequently from soil samples. Many of the species recovered in this study have not previously been reported from eastern Australia, reinforcing that Phytophthora species are widespread, abundant and diverse in natural ecosystems. We have probably been underestimating Phytophthora diversity in Australia.
\end{abstract}

\author{
Key words: \\ Eucalyptus \\ habitat disturbance \\ host preference \\ plant pathology \\ tree diseases
}

Article info: Submitted: 3 August 2015; Accepted: 24 February 2016; Published: 2 March 2016.

\section{INTRODUCTION}

Although Phytophthora causes serious diseases worldwide in agriculture, horticulture and natural ecosystems, it is only recently that accurate identification of many species of these important plant pathogens has been made possible using molecular methods. The number of described species is rapidly increasing, with at least 124 species now described (Scott et al. 2013, Martin et al. 2014), allowing a more comprehensive understanding of the distribution of these destructive pathogens (Hansen et al. 2012). When developing a PCR-based molecular toolbox, Schena et al. (2008) focused on 15 Phytophthora species that cause a decline in forests and other natural ecosystems. However, Jung et al. (2005) suggest that all Phytophthora species have the potential to cause plant health decline in natural ecosystems, particularly when there are assemblages of different introduced species present, and conditions are conducive for disease development (Scott et al. 2013).

In natural communities in Australia, the attention has been largely on $P$. cinnamomi. Elsewhere, studies on Phytophthora species diversity have focussed on the few species most destructive in the horticultural and agricultural industries (Hansen et al. 2012). Phytophthora cinnamomi has the broadest host range of all Phytophthora species and is considered an aggressive forest pathogen (Robin et al. 2012). Phytophthora cinnamomi occurs widely across Australia and is recognised by the Federal Government as 'a key threatening process' to Australia's biodiversity (Environment Protection and Biodiversity Conservation Act 1999, Environment Australia 2001). The impact of $P$. cinnamomi is greatest in the natural communities of the south-west and south-east of Australia, where it has caused the loss of animal species along with changes in species abundance and population structure (Cahill et al. 2008), also resulting in changes in floristic structure, diversity, and ecological processes (Shearer et al. 2004, McDougall et al. 2005). In south-west Western Australia (WA), which contains four of Australia's 15 biodiversity hotspots (Department of Environment 2015), it has been estimated that there are 2284 plant species that are susceptible to $P$. cinnamomi (Shearer et al. 2004). McDougall (2005) compiled a list of over 1460 species known to be susceptible, after $P$. cinnamomi had been isolated from infected plants or found in susceptibility testing. This represents only about $5 \%$ of Australia's vascular plants and so the effect of $P$. cinnamomi on most Australian plants is still unknown (Cahill et al. 2008). Due to the focus on $P$. cinnamomi, particularly in natural ecosystems, there is a paucity of information on the nature and extent of other Phytophthora species present in natural ecosystems. We now

๑ 2016 International Mycological Association

You are free to share - to copy, distribute and transmit the work, under the following conditions:

Attribution: $\quad$ You must attribute the work in the manner specified by the author or licensor (but not in any way that suggests that they endorse you or your use of the work).

Non-commercial: $\quad$ You may not use this work for commercial purposes.

No derivative works: You may not alter, transform, or build upon this work.

For any reuse or distribution, you must make clear to others the license terms of this work, which can be found at http://creativecommons.org/licenses/by-nc-nd/3.0/legalcode. Any of the above conditions can be waived if you get permission from the copyright holder. Nothing in this license impairs or restricts the author's moral rights. 
know that there are several other pathogenic Phytophthora species in WA (Scott et al. 2009, Rea et al. 2010, 2011, Crous et al. 2011, 2012, 2014, Jung et al. 2011, Aghighi et al. 2012), but very little is known about their diversity and distribution across Australia.

Reports of Phytophthora in irrigation water date back to 1921 (Hong \& Moorman 2005). Clade 6 Phytophthora species are dominant in water surveys (Reeser et al. 2011) where they may colonize leaves and other plant debris (Brasier et al. 2003, Jung et al. 2011, Reeser et al. 2011, Hansen et al. 2012). In northern Spain, High Throughput Sequencing (HTS) detected greater diversity of Phytophthora species in water than from soil samples indicating the importance of water environments as a source of inoculum (Català et al. 2015). In a small study in Victoria, isolation of Phytophthora species varied with season, bait type, and type of water filter used (Smith et al. 2009). Within one sampling season in WA, 12 Phytophthora species and two hybrids were isolated from baits in 48 waterways (Hüberli et al. 2013), emphasising the importance of surveying water bodies.

In Victoria, most of the published research on Phytophthora in natural ecosystems has focussed on $P$. cinnamomi across the south of the state in the Grampians, the Brisbane Ranges, Wilson's Promontory and East Gippsland (Cahill et al. 2008). Gibson et al. (2002) compiled a map of 495 sites where $P$. cinnamomi had been isolated between 1976 and 2001, with isolations occurring across most of the state. A formal assessment of the presence of $P$. cinnamomi within a $70 \mathrm{~km}$ survey corridor was undertaken prior to the commencement of construction activities of the Sugarloaf Pipeline, north east of Melbourne, in southern Victoria. Opportunistically isolating all Phytophthora species recovered from water baits and soil samples provided an insight into the assemblage of Phytophthora species in the region.

\section{MATERIALS AND METHODS}

\section{Site description}

As part of the Melbourne metropolitan water supply, the Sugarloaf Pipeline carries water from the Goulburn River at Killingworth (165 m AMSL) north of Yea (ca $100 \mathrm{~km}$ northeast of central Melbourne) to the Sugarloaf Reservoir in the Yarra Ranges (ca $5 \mathrm{~km}$ west of Yarra Glen) (Fig. 1). The parent material of the soils were principally siltstone and minor sandstone of the Humevale Formation, Quaternary alluvium on drainage line, and a minor occurrence of siltstone and shale of the Dargile Formation within the Sugarloaf reserve The soil $\mathrm{pH}$ was mostly $<5.5$, with a couple of instances of $\mathrm{pH} 5.5$ to 6.5 . Along the corridor, the median annual rainfall ranged from $700 \mathrm{~mm}$ (Yea) to $1300 \mathrm{~mm}$ on the Great Dividing Range (GDR) to $<600 \mathrm{~mm}$ around Sugarloaf Reservoir (Fig. 1). The study area encompassed two catchments separated by the GDR. Locations 1-3 are north of the GDR (Fig. 1)

Along the corridor there were approximately 12 of Victoria's 300 Ecological Vegetation Communities (EVCs) (DSE 2003) including nine classes of forest and complexes: lowland, riparian, heathy dry, shrubby dry, grassy dry, herbrich, damp, wet and swampy forests; and three classes of woodlands: grassy, gully, and riparian (Table 1).

\section{Experimental design}

Stream baiting was used to isolate Phytophthora species from streams and minor water bodies at 21 locations (Table 2) along the entire length of the pipeline easement -25 bait bags were deployed. In addition, 249 soil samples were collected for baiting from native forest and woodland sites, where the risk of damage to vegetation from Phytophthora was greatest.

\section{Stream baiting}

Floating mesh bait bags $(30 \times 30 \mathrm{~cm})$ were left in situ for 9 to $10 \mathrm{~d}$ in the water bodies (Table 2) before all baits were retrieved in one operation. All streams, whether perennial or intermittent, were flowing at the time they were baited, although rainfall records for five weather stations on, or adjacent to, the survey corridor showed a median reduction in mean monthly rainfall of $64 \%$ for the month prior to baiting (September). All static water bodies were at, or near, full capacity.

Baits included in each bag were 2-d-old lupin seedlings (Lupinus angustifolius; Erwin \& Ribiero 1996), young, near fully expanded leaves of oak (Quercus robur; Jung et al. 1996, Balci et al. 2007), and immature leaves of sweet pittosporum (Pittosporum undulatum; Smith et al. 2009). Segments of leaves with signs of infection (water soaked to brown or black lesions) were plated onto a selective agar medium (NARPH; Hüberli et al. 2000), from which primary isolates were again transferred to NARPH medium and then to half strength potato dextrose agar (PDA, or $1 / 2$ PDA; Becton Dickinson, Sparks, MD, USA).

\section{Soil baiting}

Soil samples were collected from 10 EVCs and two complexes (Table 1), often from multiple sites. These samples were collected from the pipeline easement from Glenburn to south of Kinglake $(14 \mathrm{~km})$ incorporating Toolangi State Forest, Paul's Range State Forest and Sugarloaf Reservoir Reserve $(1.75 \mathrm{~km})$.

Each soil sample (250-400 g) was taken, where possible, from within the $30 \mathrm{~m}$ pipeline easement. The elevation range for sample collection was between 185 and 390 m AMSL. Individual sampling points were generally selected using two criteria: the presence of dead or unhealthy individuals of known $P$. cinnamomi host species; or if potential hosts were absent, then suitable topography or presence of disturbance that were likely to be favourable for the introduction and survival of the pathogen (i.e. earthworks for roads, forest tracks, low relief and/or water gaining damp microsites).

Within $16 \mathrm{~d}$ of collection, the presence of Phytophthora species in soils were assessed using 2-d-old lupin seedlings (Lupinus angustifolius) and immature near fully expanded leaves of holm oak (Quercus ilex) as baits following the methods of Marks \& Kassaby (1974). All lupin roots, and sections of oak leaves showing signs of infection, were plated onto NARPH medium. A second round of baiting was conducted $9 \mathrm{~d}$ after the first baiting using Eucalyptus sieberi cotyledons. All Phytophthora species were further purified on NARPH medium and maintained on $1 / 2$ PDA for longer-term storage. 
Lowland and Foothill Forest

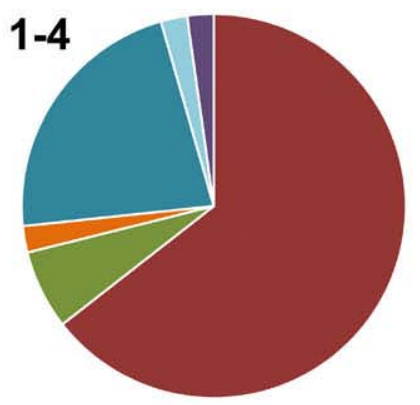

Damp and Wet Forest

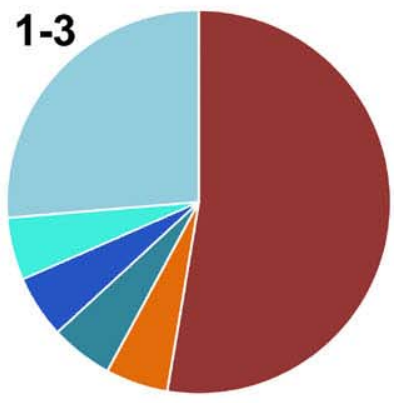

Shrubby Foothill and Dry Forest

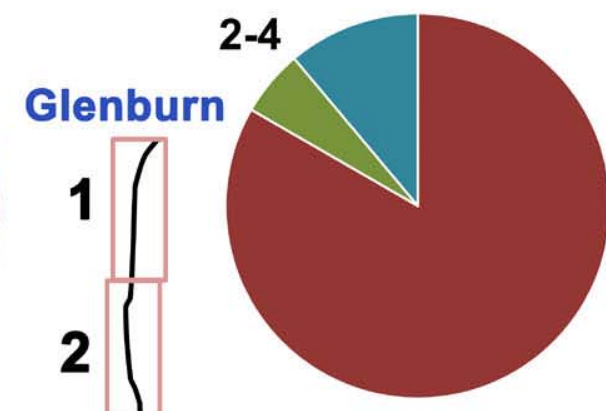

Fern Swamp

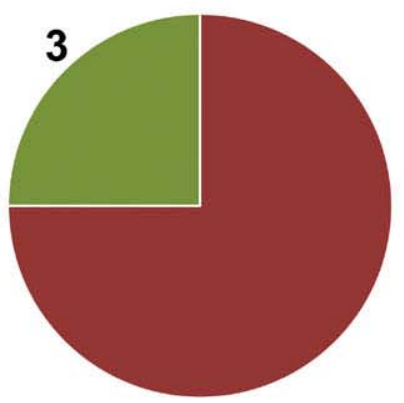

Creekline and Mosaic

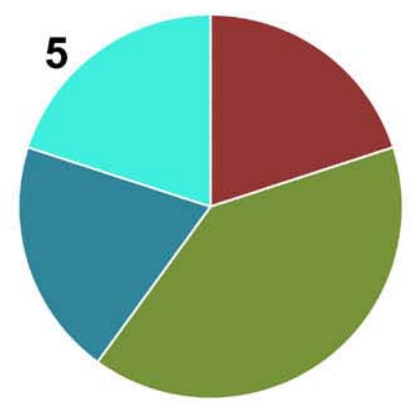

Fig. 1 Location of survey northeast of Melbourne, Victoria (bottom left). Proportion of each Phytophthora species to total number of isolates from soil in Victoria's Ecological Vegetation Classes (EVC). Lowland and Foothill Forest is a combination of EVC16 and 23, Damp and Wet Forest is a combination of EVC29 and 30. Shrubby Foothill and Dry Forest is a combination of EVC20 and 45, while Creekline and Mosaic is a combination of EVC164 and Mosaic. Fern Swamp is EVC721. The location (1-5) along Sugarloaf Pipeline Alliance easement, from Glenburn to Sugarloaf Reservoir, is noted next to the relevant pie chart. Locations 1-3 are north of the Great Dividing Range (GDR). Data not included if fewer than 4 isolates were recovered from EVC.

\section{Isolate identification}

After subculture on NARPH medium, putative Phytophthora isolates were grown on $1 / 2$ PDA, sorted based on colony morphology, and representative isolates were selected for molecular identification (130 of 186 isolates).

DNA extraction from mycelium was carried out using the method of Andjic et al. (2007). For each isolate, the region spanning the internal transcribed spacers (ITS1-5.8SITS2) region of the ribosomal DNA was amplified using the primers ITS-6 (Cooke et al. 2000) and ITS-4 (White et al. 1990), with the PCR reaction reagents and conditions as described by Andjic et al. (2007). For identification purposes, ITS templates were sequenced with an ITS-4 primer. The cleanup of PCR products and sequencing reactions were as described in Sakalidis et al. (2011). Sequence data for the ITS region were initially cleaned and subsequent manual adjustments made in Geneious v. 7.0.4 (Drummond et al. 2011). Ambiguous bases were coded according to the IUPAC nucleotide code. Identification was initially based on BLAST searches in GenBank (http://blast.ncbi.nlm.nih.gov), but in all cases, sequence data from closely related species were obtained from GenBank or from our own unpublished sequence data, and alignments and analysis were carried out in Geneious.

Almost $20 \%$ of isolates had ITS sequences that were highly polymorphic, and these were identified as Clade 6 hybrids by comparing these sequences to those obtained in previous studies (Nagel et al. 2013a, Burgess 2015). 


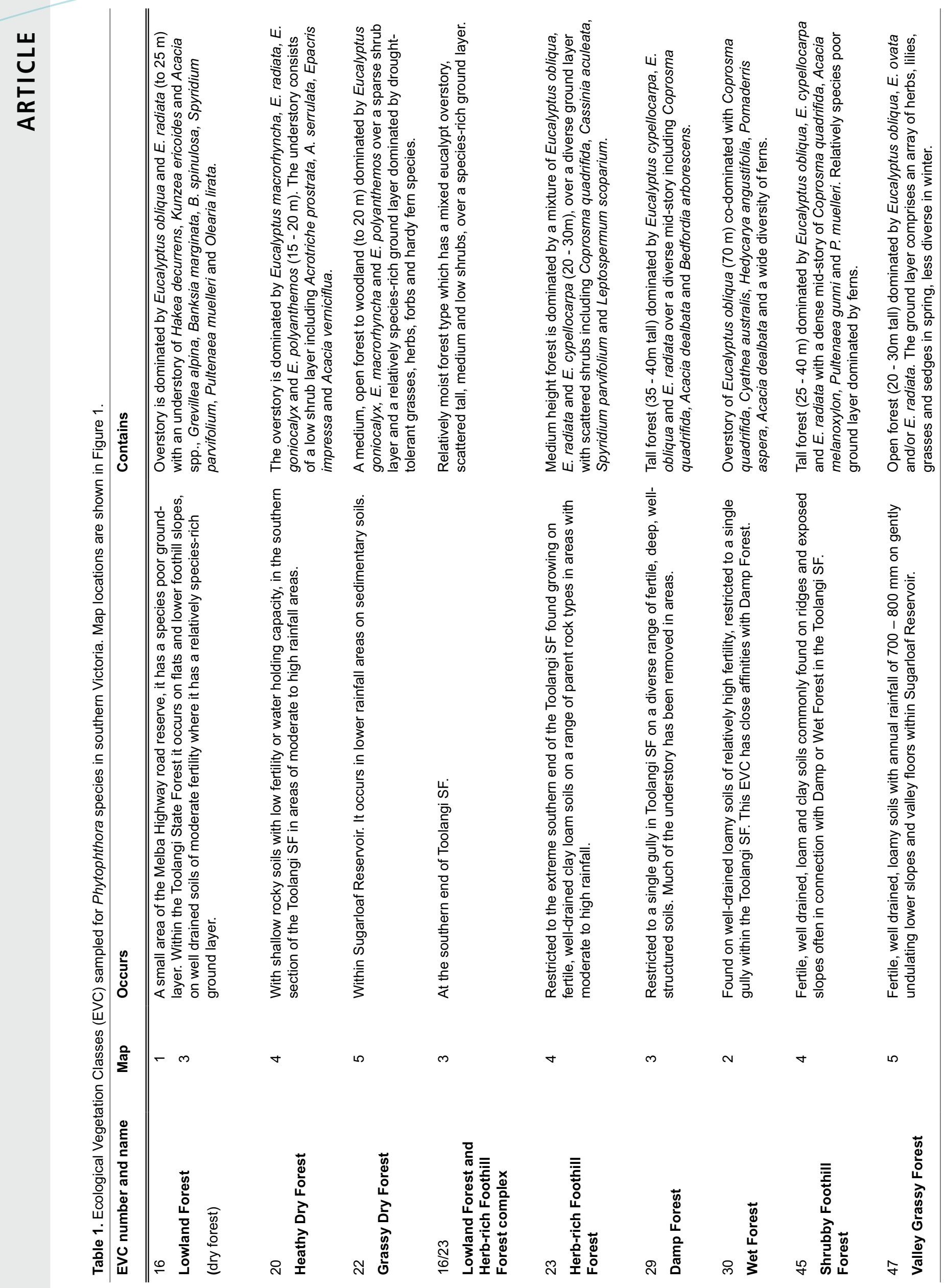




\section{RESULTS}

The soil and water sampling yielded 186 Phytophthora isolates; based on molecular identification 130 of these isolates corresponded to species and hybrids from Clades 2, and 6-9 (Tables 2-3). The remaining 56 isolates had the same cultural morphology as species from Clade 6 but were not sequenced and, thus, cannot be confidently assigned to a species (Table 3). Phytophthora cinnamomi was the most commonly found species, comprising $31 \%$ of all isolations, and almost half of the soil isolations. Of the species isolated, only $P$. fallax and Clade 6 hybrids were recovered from both soil and water.

\section{Stream baiting}

Sixty-four Phytophthora isolates were obtained from the water baits (Table 3), with one to three Phytophthora isolates recovered from each baiting location (Table 2). All but $P$. cryptogea and $P$. fallax were from Clade 6 (Table 3). Phytophthora thermophila was the most widespread species, with nine isolates found at eight different locations, both at permanent and intermittent water bodies (Table 3). Half of the isolates were unidentified Clade 6 Phytophthora species and were widespread as they were collected from 18 of the 21 locations sampled. While there were six species of Phytophthora isolated from both types of water bodies, there were more isolates from permanent (40) than intermittent water bodies (24).

\section{Soil samples}

From the 249 soil samples, we obtained 122 isolations of Phytophthora, which included six identified species, while 24 isolates were not identified to species level. Phytophthora species recovered were from Clades 2, 6, 7, and 9 (Table 3). The most commonly isolated species, $P$. cinnamomi was found in all but four of the EVCs and these were all EVCs from which low numbers of samples were collected; Grassy Dry Forest (8 samples), Herb-rich Foothill Forest (7), Wet Forest (4), and Mosaic (8).

The EVCs with the highest yield of Phytophthora isolates were the vegetation types with the greatest soil moisture (EVC 16, 47, 164 and 721). The drier forest classes (EVC 20, 22, 23 and 45) yielded Phytophthora from 8.8 to $37 \%$ of the samples. The Damp Forest, found between Glenburn and Kinglake (Fig. 1, map location 1), yielded the greatest number of Phytophthora species. While over half of the isolates were either $P$. cinnamomi or unidentified clade 6 Phytophthora species, there were an additional nine isolates representing four species; $P$. elongata, $P$. gonapodyides, $P$. gregata, and $P$. multivora (Fig. 1). Most recoveries of $P$. cinnamomi were from the Toolangi State Forest, north of the Kinglake-Healesville Road (Fig. 1, map locations 2-4).

The Clade 6 hybrids were found in map locations 1-3 (Fig. 1), and only occurred in the Lowland Forest, Lowland Forest and herbrich Foothill Forest complex, Damp Forest and the Shrubby Foothill Forest.

The lowest diversity of Phytophthora species was in the area sampled close to Sugarloaf Reservoir (map sector 5), with the Valley Grassy Forest, Creekline Herb-rich Woodland and the Mosaic EVCs only yielding nine Phytophthora isolates; three $P$. cinnamomi, one $P$. gregata, one $P$. elongata, and four unidentified Phytophthora isolates (Fig. 1, Table 4). This is an area with vegetation and soil conditions that are generally unfavourable for the recovery of Phytophthora, mostly occurring on relatively shallow soils with northern and western aspects. 


\section{DISCUSSION}

From an area north-east of Melbourne, Victoria (approximately $140 \mathrm{~km}^{2}$ ), 13 Phytophthora species were isolated by soil and water baiting. Most of these species have host ranges that include native and/or horticultural important plant taxa (Hüberli et al. 2013). Phytophthora cinnamomi was the most commonly isolated species from the rhizosphere, even from beneath asymptomatic vegetation. Overall, more Phytophthora species were recovered from the lower lying areas of wetter vegetation than from the dry vegetation classes. Every water bait yielded Phytophthora. This is one of the first studies in Victoria to survey soils in natural systems for Phytophthora species other than P. cinnamomi.

\section{Species diversity in soil and water samples}

There was low diversity in the Phytophthora species isolated from individual soil samples. After $P$. cinnamomi $(47 \%$ of soil recoveries), the second most common species was $P$. elongata, comprising almost $10 \%$ of soil recoveries. Phytophthora elongata was recovered from five of the moist EVCs containing sandy loams and clay soils, and known hosts from Myrtaceae, Proteaceae, Epacridaceae, Xanthorrhoeaceae, and Iridaceae (Rea et al. 2010) were all abundant in these EVCs. Phytophthora elongata was found to be as aggressive as $P$. cinnamomi in soil infestation tests (Rea et al. 2010). Clade 6 species and hybrids comprised almost $20 \%$ of soil isolations, challenging the assumption that they are generally associated with waterways. Further surveys, combined with pathogenicity testing of isolates, are required to determine what role Clade 6 species and hybrids play in natural ecosystems.

Isolates identified from water samples belonged predominantly to Clade 6 , with only one isolate of $P$. cryptogea from Clade 8 and an isolate of $P$. fallax from Clade 9. There were more recoveries from the permanent water bodies than the intermittent sites, but there were an equal number of species from the two types of water bodies, however only Clade 6 species were recovered from intermittent water bodies. Phytophthora thermophila, the most widespread species, is closely related to three species known only from Western Australia, P. litoralis, P. fluvialis, and $P$. moyootj (Crous et al. 2014). The high optimum and maximum temperatures for growth of $P$. thermophila (Jung et al. 2011) might contribute to its recovery from intermittent sources as well as permanent water bodies. Based on our stream recoveries, it could be speculated that many of the unidentified isolates recovered from intermittent sites would belong to Phytophthora Clade 6.

\section{Distribution of Phytophthora cinnamomi}

The high recovery of $P$. cinnamomi within the study area was anticipated because there are records of the presence of this pathogen from locations along the GDR, both east and west of the study area, at Toolangi (Marks et al. 1972) and Kinglake National Park in 1973 (Weste \& Marks 1974, Duncan \& Keane 1996, Gibson et al. 2002). The survey followed a route that has been used for passage across the GDR from Melbourne to the Murray-Goulburn pastoral regions and goldfields since European settlement in 1835.
Given the history of the travel route, the proximity to areas that were converted to agriculture, and a long history of timber harvesting in the area, it is conceivable that exotic species such as $P$. cinnamomi have been introduced to the area.

Phytophthora cinnamomi was recovered most frequently on the northern side of the GDR, frequently from sampling points where there were no signs of disease in plants that could have been attributed to Phytophthora. In contrast, $P$. cinnamomi was recovered from only one of 45 samples (in EVC20) immediately south of the crest of the GDR. The difference in recoveries between north and south of the GDR probably cannot be attributed to the relative abundance of hosts within EVCs. The total number of plant species present known to be susceptible to $P$. cinnamomi (Podger \& Brown 1989, Gibson et al. 2002, Weste et al. 2002) was 29-30 species north of the GDR, and 19-20 species south of the GDR (Sugarloaf Pipeline Alliance 2008). The mean number of dominant susceptible hosts (ground covers, over- and understory) within each EVC ranged between one and six species, with means of 2.2 and 3.25 , north and south of the GDR, respectively. Given the abundance of possible hosts, environmental factors, such as topography and soils, might explain the difference in frequency of recovery of $P$. cinnamomi. Four common overstory species within the survey area (Eucalyptus obliqua, E. macrorhyncha, E. radiata, and E. baxteri) have been shown to be highly susceptible to $P$. cinnamomi at some sites within Victoria. This occurs on some soils that can be alternatively very wet, which favours rapid proliferation of the pathogen, then dry, leading to death of infected plants through drought stress, with mortality rates between 40 and $100 \%$ (Weste 1975, Weste et al. 1973, 1976 , 2002). Nearly all sampling points north of the GDR were located 10 s to 100 s of metres downslope of high points in the landscape, and therefore water gaining, in contrast to south of the range where sampling points were at, or near, a ridgeline and therefore relatively dry and less likely to be conducive to disease expression.

Recent drought and fire concealed signs of disease caused by $P$. cinnamomi and other Phytophthora species. The survey was conducted toward the end of the Millennium Drought (2001-2009; van Dijk et al. 2013), and drought effects on plants were most likely to have been confused with signs of disease. Part of the survey area had been burnt 2-3 yr prior to the survey which would have removed diseased and dead host plants and therefore reduced the opportunity to sample symptomatic plants and recover Phytophthora species, potentially leading to an underestimation of presence and diversity.

Although there were abundant susceptible hosts, particularly among the Eucalyptus overstory, there was only one only area with consistent signs of disease typical of $P$. cinnamomi; a relatively high proportion of death of Xanthorrhoea minor within Lowland Forest (EVC16; map location 1) where $P$. cinnamomi was recovered from most samples collected. In WA, disease fronts are often apparent, but in the eastern states of Australia the presentation of symptoms in the natural ecosystem can be described as a mosaic (O'Gara et al. 2005), making the identification of infested areas very difficult. The current survey shows how cryptic this pathogen can be as there were few signs of 
Table 3. Number of isolates of Phytophthora species from soil and water baiting (permanent or intermittent water bodies) from the Sugarloaf Pipeline easement between Yea and Sugarloaf Reservoir, Victoria.

\begin{tabular}{|c|c|c|c|c|c|}
\hline \multirow[b]{2}{*}{ Identification } & \multirow[t]{2}{*}{ Clade } & \multirow[t]{2}{*}{ Soil baiting } & \multicolumn{2}{|c|}{ Water baiting } & \multirow[t]{2}{*}{ Total isolates } \\
\hline & & & permanent & intermittent & \\
\hline P. elongata & 2 & 11 & & & 11 \\
\hline P. multivora & 2 & 3 & & & 3 \\
\hline P. amnicola & 6 & & 1 & 2 & 3 \\
\hline P. chlamydospora & 6 & & 2 & & 2 \\
\hline P. gonapodyides & 6 & 1 & & & 1 \\
\hline P. gregata & 6 & 2 & & & 2 \\
\hline P. thermophila & 6 & & 5 & 4 & 9 \\
\hline P. "personii" & 6 & & & 1 & 1 \\
\hline P. "hennops" & 6 & & 1 & & 1 \\
\hline P. "paludosa" & 6 & & 1 & & 1 \\
\hline Clade 6 hybrids & 6 & 22 & 10 & 3 & 35 \\
\hline Clade 6 (unidentified) & & 24 & 20 & 12 & 56 \\
\hline P. cinnamomi & 7 & 58 & & & 58 \\
\hline P. cryptogea & 8 & & & 1 & 1 \\
\hline P. fallax & 9 & 1 & & 1 & 2 \\
\hline Total & & 122 & & & 186 \\
\hline
\end{tabular}

disease in spite of the abundance of susceptible hosts and a high frequency of recovery of the pathogen. The survey area contains an old infested site (map location 2-4), where a decline in recovery over time has been recorded (Weste 2003).

\section{Comparison to other regions in Australia and worldwide}

Soil sampling in southeast Queensland and central New South Wales revealed eight Phytophthora species (Scarlett et al. 2015). P. cinnamomi was also the most frequently isolated species, and like the current study, $P$. multivora and $P$. cryptogea were also isolated. While there were only six species identified from all the soil samples in the current study, the use of amplicon HTS may have resulted in many more species being identified. For instance, in Italian chestnut (Castanea sativa) groves, Vannini et al. (2013) found nine and 15 species using baiting and HTS, respectively. HTS in northern Spain detected 35 Phytophthora species, with species from all clades except Clades 5 and 9 (Català et al. 2015). Thus, the Australian assemblages may be more complex than what are detected by baiting alone.

The dominant Phytophthora species found in soil samples varies from region to region throughout the world, and would be largely dependent on host species, environmental conditions and human and animal vectored spread. Australian studies, including the current study, have identified $P$. cinnamomi (Clade 7) as the dominant soil species (Smith et al. 2009, Hüberli et al. 2013), while in South Africa $P$. multivora (Clade 2) comprised $40 \%$ of isolates (Oh et al. 2013), P. syringae (Clade 8) was the dominant species in Argentina (Greslebin et al. 2005), P. plurivora (Clade 2) from Spanish oak forests (Perez-Sierra et al. 2013), chestnut forests (Vannini et al. 2013) and $P$. chlamydospora (Clade 6) in Chinese oak forests (Huai et al. 2013). Despite having different dominant species, there were more similarities between the Phytophthora assemblages found in Australia and South Africa where there were five species in common, than with species reported in the northern hemisphere (0-2; Perez-Sierra et al. 2013, Vannini et al. 2013, Huai et al. 2013) and Argentina (2; Greslebin et al. 2005). However, until systematic surveys are undertaken across continents with similar sampling intensity, these comparisons are purely speculative.

Within Australia, Phytophthora species also appear to be relatively abundant in natural streams as found in the US (Hansen \& Delatour 1999, Hwang et al. 2007, Sutton et al. 2009, Sims et al. 2015), South America (Greslebin et al. 2005), Asia (Ho et al. 2002) and South Africa (Nagel et al. 2013b, Oh et al. 2013). In an intrastate comparison, stream baiting for Phytophthora species yielded nine species isolated from eight sites east of Melbourne (Smith et al. 2009), but had no definitive overlap with species identified from water samples in the current study although there is only $50 \mathrm{~km}$ between the two survey sites. These differences can be attributed to the season of the survey and the bait types used. For instance, Smith et al. (2009) showed that different bait types yielded different Phytophthora species from the same source, which also varied according to season. While Smith et al. (2009) isolated $P$. cinnamomi, $P$. "citricola" (potentially $P$. multivora or $P$. elongata) and $P$. gonapodyides from water samples, $P$. cinnamomi and $P$. gonapodyides were present only in soil samples in the current study. None of these species were found in WA waterways where $P$. inundata and $P$. thermophila were common and where most species were recovered from $B$. attenuata and $P$. undulatum leaves (Hüberli et al. 2013). The current survey found six species that were not detected previously in Victoria $P$. amnicola, $P$. thermophila, $P$. "personii", $P$. "hennops", $P$. "paludosa" and $P$. fallax. Most notably, Smith et al. (2009) recovered $P$. cinnamomi from water using mature eucalypt leaves as bait, and only in their 
Table 4. Yield of Phytophthora isolates from soil samples taken in relation to Ecological Vegetation Class (EVC details in Table 1).

\begin{tabular}{|c|c|c|c|}
\hline Ecological Vegetation Class (EVC \#) & $\begin{array}{l}\text { Total samples } \\
\text { collected }\end{array}$ & $\begin{array}{l}\text { Number of samples } \\
\text { yielding Phytophthora }\end{array}$ & $\begin{array}{l}\text { Yield for vegetation } \\
\text { class } \\
(\%)\end{array}$ \\
\hline Fern Swamp (721) & 4 & 4 & 100.0 \\
\hline Valley Grassy Forest (47) & 7 & 6 & 85.7 \\
\hline Lowland Forest (16) & 52 & 37 & 71.2 \\
\hline Creekline Herb-rich Woodland (164) & 3 & 2 & 66.7 \\
\hline Damp forest/Shrubby Foothill Forest complex (29/45) & 22 & 15 & 68.2 \\
\hline Lowland and Herb-rich Foothill Forest complex (16/23) & 32 & 18 & 56.3 \\
\hline Wet forest (30) & 4 & 2 & 50.0 \\
\hline Damp Forest (29) & 50 & 24 & 48.0 \\
\hline Grassy Dry Forest (22) & 8 & 3 & 37.5 \\
\hline Herb-rich Foothill Forest (23) & 7 & 2 & 28.6 \\
\hline Heathy Dry Forest (20) & 18 & 5 & 27.8 \\
\hline Mosaic & 8 & 1 & 12.5 \\
\hline Shrubby Foothill Forest (45) & 34 & 3 & 8.8 \\
\hline Total & 249 & 122 & \\
\hline
\end{tabular}

summer survey. Neither the current study, nor Huberli et al. (2013) used mature eucalypt leaves or sampled during the height of summer. The multi seasonal surveys and comparison of baits undertaken by Smith et al. (2009) has demonstrated a more extensive study, of preferred baits comparing local species, mature and immature leaves, and seedlings, needs to be undertaken to determine the optimal bait, along with consideration of seasonal variations including water temperature and flow rates.

The species recovered by stream baiting in the current study that were in common with the WA study (Hüberli et al. 2013) were $P$. amnicola, $P$. cryptogea and $P$. thermophila. From WA, there were 12 Phytophthora species and two hybrids recovered (Hüberli et al. 2013). The total number of isolates and hybrids found were similar, and $P$. thermophila was found to be widespread in waterways, while $P$. cryptogea and $P$. multivora were rarely encountered (Hüberli et al. 2013). Phytophthora gonapodyides was only recovered once from soil from the Damp Forest EVC in the current study, and once from water by Smith et al. (2009), while $P$. chlamydospora was isolated infrequently in soil and water samples in Victoria, but never in WA (Hüberli et al. 2013). The Clade 6 hybrids were found in both soil and water samples in the current study, with nearly $40 \%$ of the soil isolates identified as hybrids being recovered from Damp or Wet forest EVCs (29 and 30), and all from wet microsites regardless of EVC. Clade 6 hybrids $(P$. amnicola $\times P$. chlamydospora and $P$. thermophila $x P$. amnicola) were also detected in water samples in South Africa (Nagel et al. 2013a). This suggests that Clade 6 hybrids are predominantly aquatic or riparian.

While the key species isolated from water are Clade 6 and deemed to be largely saprophytic (Brasier et al. 2003, Hansen et al. 2012), morphologically similar species such as $P$. gonapodyides and $P$. chlamydospora (Oh et al. 2013) can be opportunistic and sometimes aggressive tree pathogens (Brown \& Brasier 2007, Jung et al. 2011). Phytophthora gonapodyides and $P$. chlamydospora are widespread species commonly isolated from waters and riverbank soils around the world (Brasier et al. 2003, Greslebin et al. 2005, Reeser et al. 2011, Scibetta et al. 2012, Nagel et al. 2013a). While these species are common in the Northern Hemisphere and the one study undertaken in South America (Greslebin et al. 2005), however, it is not the case for South Africa (Oh et al. 2013) or Australia. Phytophthora gonapodyides and $P$. chlamydospora are rarely recovered in Australia, instead other Clade 6 Phytophthora species and hybrids are more common (Hüberli et al. 2013, Burgess 2015). Regardless of the continent, Clade 6 species dominate the waterways.

There are several potential explanations for the community differences in the intrastate comparison; variation in seasonal and geographical differences have been reported (Smith et al. 2009, Reeser et al. 2011, Hansen et al. 2012) and sampling bias has been demonstrated depending on different baits used (Smith et al. 2009, Sutton et al. 2009, Hüberli et al. 2013). Hüberli et al. (2013) demonstrated that no single plant bait isolated all species. However, Reeser et al. (2011) attests that the diversity of Phytophthora species recovered from forest streams in Oregon and Alaska was not affected by the type of bait used but it did affect the number of isolations. Filtration, rather than baiting, provided a greater diversity and has the potential to capture the slow growing species and those with particular growth requirements (Reeser et al. 2011, Català et al. 2015). This emphasizes the need for sampling to be undertaken over different seasons with multiple methods, using a range of baits, and from multiple locations in order to thoroughly survey an area.

\section{CONCLUSIONS}

This study has demonstrated that, like many other regions in the world, there is a diverse assemblage of Phytophthora species in natural ecosystems in Victoria. Using the term "assemblage" to describe the groups of Phytophthora species 
rather than "community" shows our limited knowledge of the taxonomy, diversity and dynamics of this pathogenic genus (Reeser et al. 2011, Scibetta et al. 2012). Phytophthora cinnamomi remains the most prominent species in the soil; and Clade 6 species were frequently recovered from water bodies. While the new metagenomic approach of Scibetta et al. (2012) shows promise in being able to discriminate multiple species within samples and reduce the incidence of false negatives, allowing an estimate of diversity, it will not provide isolates for identification or further studies. Català et al. (2015) presents HTS as a fast, cheap method to determine the species diversity of Phytophthora in environmental samples. However, future studies should consider baiting along with HTS to more accurately identify Phytophthora species present at a site. Australian natural ecosystems are managed to reduce the risk of spreading $P$. cinnamomi. Accurate mapping involving both baiting and HTS will facilitate identification in regions where presence cannot be determined by the death of susceptible hosts. There have been very few studies of Phytophthora diversity and distribution in natural ecosystems in Australia, and there is limited knowledge of which species are endemic or invasive. Studies such as this provide the baseline of data upon which new invasive species can be identified and managed.

\section{ACKNOWLEDGEMENTS}

We gratefully acknowledge Rob Gardiner (Sugarloaf Pipeline Alliance, Yea) for his assistance with sampling. Nari Williams was involved with the establishment of the trial. We thank the anonymous reviewer for helpful suggestions and comments.

\section{REFERENCES}

Aghighi S, Hardy GEStJ, Scott JK, Burgess TI (2012) Phytophthora bilorbang sp. nov., a new species associated with the decline of Rubus anglocandicans (European blackberry) in Western Australia. European Journal of Forest Pathology 133: 841-855.

Andjic V, Barber PA, Carnegie AJ, Hardy GEStJ, Wingfield MJ, Burgess TI (2007) Phylogenetic reassessment supports accommodation of Phaeophleospora and Colletogloeopsis from eucalypts in Kirramyces. Mycological Research 111: 1184-1198.

Balci Y, Balci S, Eggers J, MacDonald WL, Juzwik J, et al. (2007) Phytophthora species associated with forest soils in Eastern and North-central U.S. oak ecosystems. Plant Disease 91: 705-710.

Brasier CM, Cooke DEL, Duncan JM, Hansen EM (2003) Multiple new phenotypic taxa from trees and riparian ecosystems in Phytophthora gonapodyides-P. megasperma ITS Clade 6, which tend to be high temperature tolerant and either inbreeding or sterile. Mycological Research 107: 277-290.

Brown AV, Brasier CM (2007) Colonization of tree xylem by Phytophthora ramorum, P. kernoviae and other Phytophthora species. Phytopathology 56: 227-241.

Burgess TI (2015) Molecular characterization of natural hybrids formed between five related indigenous clade 6 Phytophthora species. PLoS ONE: 10.1371/journal.pone. 0134225

Cahill DM, Rookes JE, Wilson BA, Gibson L, McDougall KL (2008) Phytophthora cinnamomi and Australia's biodiversity: impact, predictions and progress towards control. Australian Journal of Botany 56: 279-310.

Català S, Pérez-Sierra A, Abad-Campos P (2015) The use of genusspecific amplicon pyrosequencing to assess Phytophthora species diversity using eDNA from soil and water in northern Spain. PLoS ONE 10 (3): e0119311. doi:10.1371/journal. pone.0119311

Cooke DEL, Drenth A, Duncan JM, Wagels G, Brasier CM (2000) A molecular phylogeny of Phytophthora and related oomycetes. Fungal Genetics and Biology 30: 17-32.

Crous PW, Groenewald JZ, Shivas RG, Edwards J, Seifert KA, et al. (2011) Fungal Planet description sheets: 69-91. Persoonia 26: 108-156.

Crous PW, Summerell BA, Shivas RG, Burgess TI, Decock CA, et al. (2012) Fungal Planet description sheets: 107-127. Persoonia 28: 138-182.

Crous PW, Wingfield MJ, Schumacher RK, Summerell BA, Giraldo A, et al. (2014) Fungal Planet Description Sheets: 281-319. Persoonia 33: 212-289.

Department of Environment (2015) Australian's 15 National Biodiversity Hotspots. Canberra: Australian Government, Department of Environment. http://www.environment.gov.au/ biodiveristy/conservation/hotspots/national-biodiversity-hotspots

DSE (2003) Victoria's Native Vegetation Management: a framework for action. [Technical Support Maps for Local Government Authorities.] Melbourne: Department of Sustainability and Environment, State of Victoria.

Drummond AJ, Ashton B, Buxton S, Cheung M, Cooper A, et al. (2011) Geneious. v5.4. http://www.geneious.com

Duncan MJ, Keane PJ (1996) Vegetation changes associated with Phytophthora cinnamomi and its decline under Xanthorrhoea australis in Kinglake National Park, Victoria. Australian Journal of Botany 44: 355-369.

Environment Australia (2001) Threat Abatement Plan for dieback caused by the root-rot fungus (Phytophthora cinnamomi). Canberra: Environment Australia.

Erwin DC, Ribeiro OK (1996) Phytophthora Diseases Worldwide. St Paul, MN: American Phytopathological Society Press.

Gibson M, Milne RT, Cahill D, Wilson B, Baker B (2002) Preliminary review of the actual and potential distribution of Phytophthora cinnamomi dieback in parks and reserves across Victoria. Ballarat: Centre for Environmental management, University of Ballarat.

Greslebin A, Hansen EM, Winton LM, Rachenberg M (2005) Phytophthora species from soil and streams of declining Austrocedrus chilensis forests in Patagonia, Argentina. Mycologia 97: 218-28.

Hansen EM, Delatour C (1999) Phytophthora species in oak forests of north-east France. Annals of Forestry Science 56: 539-547.

Hansen EM, Reeser PW, Sutton W (2012) Phytophthora beyond agriculture. Annual Review of Phytopathology 50: 359-378.

$\mathrm{Ho} \mathrm{HH}$, Zeng HC, Zheng FC (2002). Phytophthora insolita on Hainan Island. Botanical Bulletin Academia Sinica 43: 227-230.

Hong CX, Moorman GW (2005) Plant pathogens in irrigation water: challenges and opportunities. Critical Reviews in Plant Science 24: 189-208.

Huai W-X, Tian G, Hansen EM, Zhao W-X, Goheen EM, et al. (2013) Identification of Phytophthora species baited and isolated from forest soil sand streams in northwestern Yunnan province, China. Forest Pathology 43: 87-103. 
Hüberli D, Tommerup, IC, Hardy GEStJ (2000) False-negative isolations or absence of lesions may cause mis-diagnosis of diseased plants infected with Phytophthora cinnamomi. Australasian Plant Pathology 29: 164-169.

Hüberli D, Hardy GEStJ, White D, Williams N, Burgess TI (2013) Fishing for Phytophthora from Western Australia's waterways: a distribution and diversity survey. Australasian Plant Pathology 42: $251-260$.

Hwang J, Jeffers SN, Oak SW (2007) Occurrence and distribution of Phytophthora pseudosyringae in forest streams of North Carolina. Phytopathology 97: S49.

Jung T, Blaschke H, Neumann P (1996) Isolation, identification and pathogenicity of Phytophthora species from declining oak stands. European Journal of Forest Pathology 26: 253-272.

Jung T, Stukely MJC, Hardy GEStJ, White D, Paap T, et al. (2011) Multiple new Phytophthora species from ITS clade 6 associated with natural ecosystems in Australia: evolutionary and ecological implications Persoonia 26: 13-39.

Jung T, Hudler W, Jensen-Tracy SL, Griffiths HM, Fleischmann F, Osswald W (2005) Involvement of Phytophthora species in the decline of European beech in Europe and the USA. Mycologist 19: 159-166.

Marks GC, FY Kassaby (1974) Detection of Phytophthora cinnamomi in soils. Australian Forestry 36: 198-203.

Marks GC, Kassaby FY, Reynolds ST (1972) Die-back in the mixed hardwood forests of eastern Victoria: a preliminary report. Australian Journal of Botany 20: 141-154.

Martin FN, Blair JE, Coffey MD (2014) A combined mitochondrial and nuclear multilocus phylogeny of the genus Phytophthora. Fungal genetics and Biology 66: 9-32.

McDougall KL (2005) The responses of native Australian plant species to Phytophthora cinnamomi. In: Management of Phytophthora cinnamomi for biodiversity conservation in Australia. Part 2. National Best Practice. (O'Gara E, Howard K, Wilson B, Hardy GEStJ, eds): Appendix 4. Canberra: Department of the Environment and Heritage.

McDougall KL, Hobbs RJ, Hardy GEStJ (2005) Distribution of understorey species in forest affect by Phytophthora cinnamomi in south-western Australia. Australian Journal Botany 53: 813819.

Nagel JH, Gryzenhout M, Slippers B, Wingfield MJ, Hardy GEStJ, et al. (2013a) Characterization of Phytophthora hybrids from ITS clade 6 associated with riparian ecosystems in South Africa and Australia. Fungal Biology 17: 329-347.

Nagel JH, Gryzenhout M, Slippers B, Wingfield MJ (2013b) The occurrence and impact of Phytophthora on the African continent. In: Phytophthora Diseases: a global perspective (Lamour K, ed.): 204-214. Wallingford: CAB International.

O'Gara E, Howard K, Wilson B, Hardy GEStJ (2005) Management of Phytophthora cinnamomi for Biodiversity Conservation in Australia.- Part 1. A Review of Current Management. Canberra: Centre for Phytophthora Science and Management, Murdoch University.

Oh E, Gryzenhout M, Wingfield BD, Wingfield MJ, Burgess TI (2013) Surveys of soil and water reveal a goldmine of Phytophthora diversity in South African natural ecosystems. IMA Fungus 4: 123-131.

Perez-Sierra A, Lopez-Garcia C, Leon M, Garcia-Jimenez J, AbadCampos P, Jung T (2013) Previously unrecorded low temperature Phytophthora species associated with Quercus decline in a
Mediterranean forest in eastern Spain. Forest Pathology 43: 331-339.

Podger FD, Brown MJ (1989) Vegetation damage caused by Phytophthora cinnamomi on disturbed sites in temperate rainforest in Western Australia. Australian Journal of Botany 37: 443-480.

Rea AJ, Jung T, Burgess TI, Stukely MJC, Hardy GEStJ (2010) Phytophthora elongata sp. nov., a novel pathogen from the Eucalyptus marginata forest of Western Australia. Australasian Plant Pathology 39: 477-491.

Rea A, Burgess TI, Hardy GEStJ, Stukely MJC, Jung T (2011) Two novel species of Phytophthora associated with episodic dieback of kwongan vegetation of south-west Western Australia. Plant Pathology 60: 1055-1068.

Reeser PW, Sutton W, Hansen EM, Remigi P, Adams GC (2011) Phytophthora species in forest streams in Oregon and Alaska. Mycologia 103: 22-35.

Robin C, Smith I, Hansen EM (2012). Phythophthora cinnamomi. Forest Phytophthoras 2 (1): doi:10.5399/osu/fp.2.1.3041.

Sakalidis ML, Hardy GEStJ, Burgess TI (2011) Endophytes and potential pathogens of the baobab species Adansonia gregorii; a focus on the Botryosphaeriaceae. Fungal Ecology 4: 1-14.

Scarlett K, Daniel R, Shuttleworth LA, Roy B, Bishop TFA, Guest DI (2015) Phytophthora in the Gondwana Rainforests of Australia World Heritage Area. Australasian Plant Pathology 44: 335-348.

Schena L, Duncan JM, Cooke DEL (2008) Development and application of a PCR $\square$ based 'molecular tool box' for the identification of Phytophthora species damaging forests and natural ecosystems. Plant Pathology 57(1): 64-75.

Scibetta S, Schena L, Chimento A, Cacciola SO, Cooke DEL (2012) A molecular method to assess Phytophthora diversity in environmental samples. Journal of Microbiological Methods 88: 356-368.

Scott P, Burgess TI, Hardy GEStJ (2013) Globalization and Phytophthora. In: Phytophthora: a global perspective (Lamour K, ed.). 226-233. [CABI Plant Protection Series no. 2.] Wallingford: CAB International.

Scott P, Burgess TI, Barber PA, Shearer BL, Stukely MJC, et al. (2009) Phytophthora multivora sp. nov., a new species recovered from declining Eucalyptus, Banksia, Agonis and other plant species in Western Australia. Persoonia 22: 1-13.

Shearer BL, Crane CE, Cochrane A (2004) Quantification of the susceptibility of the native flora of the south-west botanical province, Western Australia, to Phytophthora cinnamomi. Australian Journal of Botany 52: 435-443.

Sims LL, Sutton W, Reeser P, Hansen EM (2015) The Phytophthora species assemblage and diversity in riparian alder ecosystems of western Oregon, USA. Mycologia 107: 889-902.

Smith BW, Smith IW, Cunnington J, Jones RH (2009) An evaluation of stream monitoring techniques for surveys for Phytophthora species in Victoria, Australia. Proceedings of the International Union of Forest Resources Organisation .Phytophthora Diseases of Forest Trees, Monterey, CA, August 26-3: 325. Albany, CA: USDA Forest Service

Sugarloaf Pipeline Project (2008) Flora and Fauna Assessment, Feb 2008. Unpublished report prepared by the Sugarloaf Pipeline Alliance.

Sutton W, Hansen EM, Reeser PW, Kanaskie A (2009) Stream monitoring for detection of Phytophthora ramorum in Oregon tanoak forests. Plant Disease 93: 1182-1186. 
van Dijk AlJM, Beck HE, Crosbie RS, de Jeu RAM, Liu YY, et al. (2013) The Millennium Drought in southeast Australia (20012009): natural and human causes and implications for water resources, ecosystems, economy, and society. Water Resources Research 49: 1040-1057.

Vannini A, Bruni N, Tomassini A, Franceshini S, Vettraino AM (2013) Pyrosequencing of environmental soil samples reveals biodiversity of the Phytophthora resident community in chestnut forests. FEMS Microbial Ecology 85: 433-442.

Weste G (1975) The distribution of Phytophthora cinnamomi within the National Park, Wilson's Promontory, Victoria. Australian Journal of Botany 23: 67-76.

Weste G (2003) The dieback cycle in Victorian forests: a 30-year study of changes caused by Phytophthora cinnamomi in Victorian open forests, woodlands and heathlands. Australasian Plant Pathology 32: 247-256.

Weste G, Marks GC (1974) The distribution of Phytophthora cinnamomi in Victoria. Transactions of the British Mycological Society 63: 559-572.
Weste G, Cooke D, Taylor P (1973) The invasion of native forest by Phytophthora cinnamomi. II Post-infection vegetation patterns, regeneration, decline in inoculum, and attempted control. Australian Journal of Botany 21:13-29.

Weste G, Ruppin P, Vithinage K (1976) Phytophthora cinnamomi in the Brisbane Ranges: patterns of disease extension. Australian Journal of Botany 24: 201-208.

Weste G, Brown K, Kennedy J, Walshe T (2002) Phytophthora cinnamomi infestation- a 24-year study of vegetation change in forests and woodlands of the Grampians, Western Victoria. Australian Journal of Botany 50: 247-274.

White TJ, Bruns T, Lee S, Taylor J (1990) Amplification and direct sequencing of fungal ribosomal RNA genes for phylogenetics. In: PCR Protocols: a guide to methods and applications (Innis MA, Gelfand DH, Snisky JJ, White TJ, eds): 315-322. San Diego: Academic Press. 